\title{
Do Geometry Self-Efficacy and Spatial Anxiety Predict the Attitudes Towards Geometry?
}

\author{
Alper Yorulmaz 1 \& Emel Çilingir Altıner² \\ 'Department of Primary Education, Mugla Sitki Kocman University, Mugla, Turkey \\ 2Department of Primary Education, Çukurova University, Adana, Turkey \\ alperyorulmaz@mu.edu.tr
}

\begin{abstract}
Self-efficacy and spatial anxiety towards geometry are stated to be effective to improve teachers' attitudes towards geometry. Therefore, it is necessary to determine the effect of geometry self-efficacy and spatial anxiety on attitude towards geometry. This determines the extent to which the pre-service primary school teachers' geometry self-efficacy and spatial anxiety predict their attitudes towards geometry. The study used the cross-sectional survey model and the sample was determined with the convenience sampling method. The sample consists of 165 pre-service primary school teachers attending a state university. To collect the data, the geometry self-efficacy scale, the spatial anxiety scale, and the geometry attitude scale were used. Multiple regression analysis was conducted in the data analysis to explain the predictors of the attitude towards geometry. It was found that the pre-service teachers' geometry self-efficacy beliefs and spatial anxiety were high while their geometry attitude was medium. Their geometry self-efficacy positively and significantly correlated with the attitude towards geometry and negatively and significantly correlated with spatial anxiety. While the sub-dimensions of geometry self-efficacy; positive self-efficacy beliefs, use of geometry knowledge, and negative self-efficacy beliefs had positive effects on the attitude towards geometry, spatial anxiety had a negative effect on the attitude towards geometry.
\end{abstract}

Keywords: Geometry self-efficacy, spatial anxiety, geometry attitude, pre-service teacher

How to Cite: Yorulmaz, A., \& Çilingir Altıner, E. (2021). Do Geometry Self-Efficacy and Spatial Anxiety Predict the Attitudes Towards Geometry?. Mimbar Sekolah Dasar, 8(2), 205-216. doi:https://doi.org/10.53400/mimbar-sd.v8i2.35914.

INTRODUCTION Recent research has shown that human progress relies on advances in science, technology, engineering, and mathematics (STEM). Therefore, understanding the factors that affect a person's ability to conduct STEM activities and eventually his/her success has become a current concern for researchers and politicians (Sokolowski, Hawes, \& Lyons, 2019). Accordingly, by conducting research aimed at addressing complex questions about the interaction between cognitive and affective factors underlying STEM performance, both a theoretical framework is provided and practical examples of how this framework can be applied could be presented. In particular, the contribution of cognitive and affective factors in mathematical fields to STEM is undeniable. One of these factors, geometry, is one of the most important branches of mathematics. In addition, the National Council of Teachers of Mathematics (NCTM, 2000) emphasizes the importance of geometry in school mathematics, stating that "geometry is a natural place for the development of students' reasoning and 
Alper Yorulmaz and Emel Çilingir Altıner, Do Geometry Self-Efficacy and Spatial Anxiety Predict...

justification skills". However, in learning geometry, students face many difficulties, and one of these difficulties is related to the affective characteristics of students (Yenilmez \& Uygan, 2010).

The emotions, preferences, values, moral rules, desires, ambitions, motives, and orientations that are desired to be imparted to students fall within the scope of the affective domain. In addition, it has been stated that there is an important interaction between attitudes, anxiety, self-efficacy, and belief which are among the affective features and learning. (Bloom, 1998, as cited in Bal, 2012).

Studies have been conducted that generally examine the relationship between other variables such as self-efficacy and mathematics performance (Abalı Öztürk \& Şahin, 2015; Ayotola \& Adedeji, 2009; Çelik, 2012; Kitsantas, Cheema, \& Ware, 2011; Öztürk, 2017; Pajares \& Miller, 1994; Terzi \& Mirasyedioğlu, 2009) or mathematics self-efficacy and computer selfefficacy (Bayturan, 2011; Işıksal \& Aşkar, 2003) and mathematics performance. In addition, according to the results of the Trends in International Mathematics and Science Study (TIMSS), it was observed that the fourth-grade students of primary school were less successful in the geometry learning area than in other learning areas of mathematics (Milli Eğitim BakanlığıÖlçme Değerlendirme ve Sınav Hizmetleri Genel Müdürlüğü (Ministry of National EducationGeneral Directorate of Assessment Evaluation and Examination Services), 2016). However, there are a limited number of studies investigating geometry-specific attitudes and selfefficacy and spatial anxiety together (Çağlayan, 2010). Moreover, given that the attitudes of primary school teachers towards geometry affect students' attitudes (Tsao, 2017) and students of the teachers having spatial anxiety are inadequate in activities requiring spatial skills (Gunderson, Ramirez, Beilock, \& Levine, 2013), research to be conducted on pre-service teachers in this regard is believed to be important. The development of pre-service teachers' attitudes towards geometry has an important place in forming positive attitudes towards geometry for the children they teach. Revealing the factors that are effective in developing the attitude towards geometry is important in the process of determining the content of undergraduate education of pre-service teachers.

To examine the attitude towards geometry, the current study was carried out with pre-service primary school teachers. The study aimed to investigate the extent to which geometry selfefficacy and spatial anxiety predict the pre-service teachers' attitudes towards geometry. Thus, this study sought an answer to the question "What is the extent to which the pre-service primary school teachers' attitudes towards geometry are predicted by geometry self-efficacy and spatial anxiety?"

\section{THEORETICAL FRAMEWORK}

Attitudes play an important role in students' geometry success (Tsao, 2017). In educational research, it is emphasized that it is important to develop a positive attitude because of the 
positive relationship between attitudes and higher achievement scores (Papanastasiou, 2000). Similarly, if students have positive attitudes towards geometry, they are expected to love geometry, participate in learning activities, and be highly successful in geometry (Bindak, 2004). Thompson (1993) defined attitude as a learned model developed through one's environment. Utley (2004) specifically defined attitude towards geometry as a set of beliefs focused on geometry, which makes a person prone to react in a particular way. Research shows that there is a positive relationship between students' geometry achievements and attitudes (Bal, 2012). For this reason, it is considered important to examine the variables that affect positive attitude development.

When the effective features affecting the process in geometry education are considered, it is thought that not only attitude but also self-efficacy belief are important. According to Bandura, self-efficacy means one's beliefs in his/her ability to organize and execute his/her action plans necessary to achieve certain goals (Bandura, 1977, as cited in Dursun, 2010). Zimmerman (1995), on the other hand, defined self-efficacy as one's judgments about his/her ability to perform a job successfully. Given the positive effect of self-efficacy belief on behaviour, it can be inferred that students' beliefs that they can learn geometry will enable them to have a positive attitude towards geometry. It can be said that the positive self-efficacy belief that requires being open to new learning will not only foster a desire to learn geometry but also develop a positive attitude towards geometry.

It is believed that pre-service teachers' geometry self-efficacy may have a positive relationship with their spatial visualization abilities (Sokolowski et al., 2019). Spatial skills are an integral part of geometry applications (Mullis \& Martin, 2017). As it is known, the development of spatial skills has been put forward as a positive indicator of the development of STEM-related skills in the future (Wai, Lubinski, \& Benbow, 2009). However, some individuals feel concerned about situations that require spatial skills-related practices to be carried out in an evaluative context. As a result, they can avoid mental activities and experiences related to spatial skills.

An important and often overlooked factor related to spatial skills is spatial anxiety, defined as fear and concern for spatial processes, which can prevent individuals from participating in experiences and opportunities that could otherwise promote the development of spatial skills. It has been observed that primary school students whose teachers have high spatial anxiety attain fewer gains in spatial skills during the school year (Gunderson et al., 2013). This is also important to understand how the teachers' feelings toward the subject areas they teach are related to the students' achievement. In this context, spatial skills associated with the geometry of learning and teaching are critical. It is important to determine the affective attitudes towards spatial relationships as they form an important component of geometry. 
Alper Yorulmaz and Emel Çilingir Alıner, Do Geometry Self-Efficacy and Spatial Anxiety Predict...

\section{METHOD}

\section{Research Design}

The current study employed the cross-sectional survey model to determine the predictor relationships between geometry self-efficacy, spatial anxiety, and geometry attitude of the pre-service primary school teachers. In the cross-sectional model, a single measurement is performed to evaluate the variables to be described (Büyüköztürk, Çakmak, Akgün, Karadeniz, \& Demirel, 2013; Fraenkel, Wallen, \& Hyun, 2019). In the current study, the model related to the predictor status of the pre-service teachers' geometry self-efficacy and spatial anxiety in terms of predicting the attitude towards geometry was tested.

\section{Research Sample}

The current study was conducted on pre-service teachers attending the Department of Primary School Teaching in a state university located in the city of Istanbul in the fall term of the 20152016 academic year. As primary school is the first place where mathematical knowledge and skills are formally taught to students, it was thought that it would be appropriate to study with pre-service primary school teachers. A total of 165 pre-service primary school teachers selected by using the convenience sampling method constituted the sample of the study. Of the participating pre-service teachers, $67.3 \%(n=111)$ are females and $32.7 \%(n=54)$ are males. In addition, $27.3 \%$ ( $n=45$ ) of the participating pre-service teachers are first-year students, $23.0 \%$ $(n=38)$ are second-year students, $21.2 \%(n=35)$ are third-year students and $28.5 \%(n=47)$ are fourth-year students.

\section{Data Collection Tools}

The tools used in the current study to collect data include a personal information form developed to determine the age and grade level of the participants, the geometry selfefficacy scale, the spatial anxiety scale, and the geometry attitude scale. Detailed information about the used scales is given below.

In the current study, the data were collected by using the "Geometry Self-Efficacy Scale", the "Spatial Anxiety Scale", and the "Geometry Attitude Scale". The "Geometry Self-Efficacy Scale" was developed by Cantürk-Günhan and Başer (2007). The scale is a five-point Likert scale consisted of 25 items and 3 sub-dimensions (positive self-efficacy beliefs, use of geometry knowledge, and negative self-efficacy beliefs). The lowest score to be taken from the scale is 25 while the highest score is 125 . Higher scores taken from the scale indicate increasing selfefficacy while lower scores indicate decreasing self-efficacy. In the original study, the Cronbach alpha reliability coefficient of the scale was .90 while in the current study, it was found to be .87 .

The "Spatial Anxiety Scale" developed by Lawton (1994) to measure the anxiety felt by the individual in situations in which spatial skills need to be used was adapted to Turkish by Dursun 
(2010). The scale is a five-point Likert scale consisted of 8 items and one dimension. The lowest score to be taken from the Spatial Anxiety Scale is 8 while the highest score is 40 . Higher scores taken from the scale indicate increasing anxiety while low scores indicate decreasing anxiety. In the Turkish adaptation of the scale, the Cronbach alpha reliability coefficient was .87 while in the current study, it was found to be .88 .

The "Geometry Attitude Scale" developed by Utley in 2007 to determine the individuals' attitudes towards geometry was adapted to Turkish by Avcu and Avcu (2015). The scale is a five-point Likert scale consisted of 25 items and 4 sub-dimensions (self-confidence, enjoying, benefit in the future, benefit in daily life). In the scale, there are 11 negative items and 14 positive items. The lowest score to be taken from the scale is 25 while the highest score is 125 and higher scores taken from the scale indicate increasing levels of positive attitude towards geometry. In the Turkish adaptation study of the scale, the Cronbach alpha reliability coefficient was .94 while it was found to be .92 in the current study.

\section{Data Collection}

The data of the current study were collected in the fall term of the 2015-2016 academic year. Before starting the administration of the scales, the necessary permissions were needed, the application form was prepared and duplicated as many as needed. After the permissions were acquired from the instructors responsible for the teaching of the courses determined for each grade level, the application was initiated. Then, the application form including the scales was administered to the pre-service primary school teachers after they received the necessary explanations in the class hour of the course selected. The pre-service teachers were included in the study on a volunteer basis.

\section{Data Analysis}

Multiple regression analysis was conducted to determine the predictors and explain the variance in the pre-service teachers' attitudes towards geometry. The variances of the multiple regression analysis were tested. To determine the outliers in the data set, $z$ values and box plots were examined and as a result, 17 pre-service teachers were excluded from the data set. To determine whether there are outliers in multivariate analyses, Mahalanobis distance values were examined and as a result, five pre-service teachers were discarded from the data set. On the data obtained from the remaining 165 pre-service teachers, skewness and Kurtosis values were calculated to determine the normality of variance. A Scree plot was also created to determine the normality of the multivariate state. To determine whether there is a high correlation between two or more predictors, correlation coefficients between the variables were calculated. When the tolerance values between the predictor variables are higher than .02 and VIF values are lower than 10, it can be said that there is no multicollinearity problem (Field, 2009). As a result of the analyses conducted, it was concluded that all the assumptions 
Alper Yorulmaz and Emel Çilingir Altıner, Do Geometry Self-Efficacy and Spatial Anxiety Predict...

required for multiple regression were satisfied. Geometry self-efficacy, spatial anxiety, and geometry attitude mean scores are evaluated as follows: between 1 and 2.33, it is low; between 2.34 and 3.67, it is medium; and between 3.68 and 5.00, it is high. The values obtained from Pearson correlation analysis conducted to determine the correlations between the variables are evaluated as follows: very weak when it is 0.19 and lower; weak when it is 0.20 0.39; medium when it is 0.40-0.59; high when it is 0.60-0.79 and very high when it is 0.80 and higher.

\section{RESULTS}

In line with the purpose of the current study, firstly, descriptive statistics were used to summarize the pre-service teachers' geometry self-efficacy, spatial anxiety, and attitudes towards geometry. Mean scores, minimum-maximum values, standard deviation, and skewness-Kurtosis values are presented in Table 1.

Table 1. Descriptive statistics for the pre-service teachers' geometry self-efficacy, spatial anxiety, and attitudes towards geometry

\begin{tabular}{lccccccc}
\hline \multicolumn{1}{c}{ Scale } & $\begin{array}{c}\text { Item } \\
\text { number }\end{array}$ & Min & Max & $\overline{\mathrm{x}}$ & sd & Skewness & Kurtosis \\
\hline Geometry self-efficacy & 25 & 1.72 & 4.72 & 3.31 & 0.59 & -0.13 & 0.17 \\
\hline $\begin{array}{l}\text { Positive self-efficacy } \\
\text { beliefs }\end{array}$ & 12 & 1.42 & 5.00 & 3.37 & 0.63 & -0.28 & 0.17 \\
$\begin{array}{l}\text { Use of geometry } \\
\text { knowledge }\end{array}$ & 6 & 1.17 & 4.83 & 3.03 & 0.72 & 0.15 & -0.03 \\
$\quad \begin{array}{l}\text { Negative self-efficacy } \\
\text { beliefs }\end{array}$ & 7 & 2.00 & 4.43 & 3.44 & 0.50 & -0.34 & -0.22 \\
\hline Spatial anxiety & 8 & 1.00 & 5.00 & 3.78 & 0.77 & -0.86 & 1.00 \\
\hline Geometry attitude & 25 & 1.48 & 4.84 & 3.36 & 0.68 & -0.17 & -0.31 \\
\hline$\quad$ Self-confidence & 9 & 1.44 & 5.00 & 3.33 & 0.85 & 0.05 & -0.69 \\
$\quad \begin{array}{l}\text { Enjoying } \\
\text { Benefit in the future }\end{array}$ & 8 & 1.38 & 4.50 & 3.49 & 0.69 & -0.62 & 0.05 \\
Benefit in the daily life & 4 & 1.00 & 5.00 & 3.28 & 0.88 & -0.31 & -0.36 \\
\hline
\end{tabular}

Examining the skewness and Kurtosis values presented in Table 1, it is seen that they are enough for the distribution to be accepted as normal (Kline, 2010). The pre-service primary school teachers' geometry self-efficacy mean score was found to be $(\bar{x}=3.31$, ss $=.59)$ at the medium level. When the geometry self-efficacy findings were examined, it was found the mean score calculated for the sub-dimension of "Negative self-efficacy beliefs" ( $\bar{x}=3.44$, ss $=.50)$ is higher than the mean scores calculated for the sub-dimensions of "Positive self-efficacy beliefs" $(\bar{x}=3.37, s s=.63)$ and "Use of geometry knowledge" ( $\bar{x}=3.03, s s=.72)$. The mean scores calculated for the sub-dimensions of geometry self-efficacy were found to be at the medium level. The mean score for the pre-service teachers' spatial anxiety was found to be high $(\bar{x}=3.78, s s=.77)$. The pre-service teachers' mean geometry attitude score was found to be at the medium level $(\bar{x}=3.36$, ss $=.68)$. The mean scores calculated for the sub-dimensions of "Enjoying" $(\bar{x}=3.49$, $s s=.69)$ and "Self-confidence" $(\bar{x}=3.33, s s=.85)$ were found to be higher than the mean scores 
calculated for the sub-dimensions of "Benefit in the future" $(\bar{x}=3.28, s s=.88)$ and "Benefit in the daily life" ( $\bar{x}=3.25, s s=.74)$ and the mean scores calculated for the sub-dimensions of geometry attitude were found to be at the medium level. In Table 2, the relationships between the preservice primary school teachers' geometry attitude, geometry self-efficacy, and spatial anxiety are presented.

Table 2. Relationships between geometry attitude, geometry self-efficacy, and spatial anxiety

\begin{tabular}{cccccc}
\hline & $\begin{array}{c}\text { Geometry } \\
\text { self-efficacy }\end{array}$ & $\begin{array}{c}\text { Negative } \\
\text { self-efficacy } \\
\text { beliefs }\end{array}$ & $\begin{array}{c}\text { Use of } \\
\text { geometry } \\
\text { knowledge }\end{array}$ & $\begin{array}{c}\text { Positive self- } \\
\text { efficacy } \\
\text { beliefs }\end{array}$ & $\begin{array}{c}\text { Spatial } \\
\text { anxiety }\end{array}$ \\
\hline $\begin{array}{c}\text { Geometry } \\
\text { attitude }\end{array}$ & $.798^{* *}$ & $.763^{* *}$ & $.646^{* *}$ & $.552^{* *}$ & $-.058^{*}$ \\
\hline
\end{tabular}

${ }^{* *} \mathrm{p}<.01,{ }^{*} \mathrm{p}<.05$

As can be seen in Table 2, there is a positive and high correlation between the geometry attitude and geometry self-efficacy $(r=.798, p<.01)$. A positive and high correlation was found between the geometry self-efficacy sub-dimensions of "Negative self-efficacy beliefs" $(r=.763$, $p<.01)$ and "Use of geometry knowledge" $(r=.646, p<.01)$. Moreover, there is a positive and medium correlation between geometry attitude and "Positive self-efficacy beliefs" ( $r=.552$, $\mathrm{p}<.01)$. Finally, a very weak and negative correlation was found between geometry selfefficacy and spatial anxiety $(r=-.058, p<.05)$.

The results of the multiple regression conducted to determine the variables predicting the attitude towards geometry are presented in Table 3.

Table 3. Multiple regression analysis was conducted to determine the attitude towards geometry

\begin{tabular}{|c|c|c|c|c|c|c|c|c|c|}
\hline \multirow[t]{2}{*}{ Model } & \multirow[t]{2}{*}{ Variable } & \multirow[t]{2}{*}{$R$} & \multirow[t]{2}{*}{$\mathrm{R}^{2}$} & \multirow[t]{2}{*}{$\Delta R^{2}$} & \multirow[t]{2}{*}{$\mathrm{F}$} & \multirow[t]{2}{*}{ B } & Std. & \multirow[t]{2}{*}{$\beta$} & \multirow[t]{2}{*}{$\dagger$} \\
\hline & & & & & & & Error & & \\
\hline \multirow[t]{2}{*}{1} & (Constant) & & & & & .608 & .186 & & 3.263 \\
\hline & Positive self-efficacy beliefs & .763 & .582 & .580 & 227.272 & .818 & .054 & .763 & 15.076 \\
\hline \multirow[t]{4}{*}{2} & (Constant) & & & & & .539 & .183 & & 2.948 \\
\hline & Positive self-efficacy beliefs & .778 & .605 & .600 & 124.255 & .656 & .075 & .612 & 8.798 \\
\hline & Use of geometry & & & & & .2020 & .066 & .214 & 3.074 \\
\hline & knowledge & & & & & & & & \\
\hline \multirow[t]{5}{*}{3} & (Constant) & & & & & -.040 & .234 & & -.169 \\
\hline & Positive self-efficacy beliefs & .798 & .637 & .630 & 94.146 & .517 & .081 & .482 & 6.394 \\
\hline & Use of geometry & & & & & .222 & .064 & .235 & 3.496 \\
\hline & knowledge & & & & & & & & \\
\hline & $\begin{array}{l}\text { Negative self-efficacy } \\
\text { beliefs }\end{array}$ & & & & & .287 & .077 & .212 & 3.741 \\
\hline 4 & (Constant) & & & & & .211 & .279 & & .755 \\
\hline
\end{tabular}


Alper Yorulmaz and Emel Çilingir Altıner, Do Geometry Self-Efficacy and Spatial Anxiety Predict...

\begin{tabular}{|c|c|c|c|c|c|c|c|c|}
\hline Positive self-efficacy beliefs & .802 & .643 & .634 & 72.007 & .522 & .080 & .487 & 6.484 \\
\hline Use of geometry & & & & & .220 & .063 & .232 & 3.474 \\
\hline \multicolumn{9}{|l|}{ knowledge } \\
\hline Negative self-efficacy & & & & & .286 & .076 & .212 & 3.749 \\
\hline \multicolumn{9}{|l|}{ beliefs } \\
\hline Spatial anxiety & & & & & -.068 & .042 & -.077 & -1.633 \\
\hline
\end{tabular}

As can be seen in Table 3, four models explaining the attitude towards geometry are significant. When Model 1 is examined, it is seen that "Positive self-efficacy beliefs" explain $58 \%$ of the total variance in the attitude towards geometry. In Model 2, "Use of geometry knowledge" explains $2 \%$ of the variance; in Model 3, "Negative self-efficacy beliefs" explains $3 \%$ of the variance and in Model 4, and "Spatial anxiety" explains $1 \%$ of the variance. Thus, the total variance explained by these variables was found to be $64 \%$. "Positive self-efficacy beliefs" were found to be the most important indicator having a positive effect on the attitude towards geometry $(\beta=.763$, $p<.05)$. Moreover, "Use of geometry knowledge" $(\beta=.214, p<.05)$ and "Negative self-efficacy beliefs" $(\beta=.212, p<.05)$ were found to be positively affect the attitude towards geometry. However, "Spatial anxiety" ( $\beta=-.077, p<.05)$ was found to have a negative and weak effect on explaining the attitude towards geometry.

\section{DISCUSSION}

The current study is aimed to determine the extent to which geometry self-efficacy and spatial anxiety predict the pre-service primary school teachers' attitudes towards geometry. At the same time, it is considered to be very important to break the cycle of the teacher having negative attitudes and accordingly causing his/her students to develop negative attitudes (Tsao, 2017). When the findings of the current study were examined in this regard, the preservice primary school teachers' positive self-efficacy beliefs were found to be higher than their negative self-efficacy beliefs and use of geometry knowledge. In addition, their spatial anxiety was high and their attitude towards geometry was medium. Similarly, Duatepe-Paksu (2013) found that the pre-service primary school teachers' geometry self-efficacy beliefs and attitudes are at the medium level. On the other hand, Ünlü, Avcu, and Avcu (2010) found that the pre-service teachers' geometry attitude scores and geometry self-efficacy scores were high. In Tsao's (2017) study with pre-service primary school teachers, it was revealed that the pre-service teachers did not like geometry and felt insufficient in geometry even though they cared about geometry. Dursun (2010) showed that pre-service teachers' geometry selfefficacy was relatively high and spatial anxiety level was low.

Another finding of the current study is that there is a positive and high correlation between the attitude towards geometry and geometry self-efficacy. Moreover, a positive and high correlation was found between the attitude towards geometry and the sub-dimensions of selfefficacy "Negative self-efficacy beliefs" and "Use of geometry knowledge". In addition, a 
medium and positive correlation was found between the attitude towards geometry and "Positive self-efficacy beliefs". In their study, Ünlü, Avcu, and Avcu (2010) found a positive and strong correlation between the pre-service teachers' attitudes towards geometry and selfefficacy beliefs. In the current study, a negative and very weak correlation was found between the pre-service teachers' geometry self-efficacy and spatial anxiety. Parallel to this, Dursun (2010) found that the pre-service teachers with higher levels of spatial anxiety got lower scores from geometry self-efficacy tests. Erkek and Işıksal-Bostan (2015) stated that a low level of spatial anxiety and a high level of self-efficacy perception increased the achievement in geography. This finding shows that spatial anxiety is correlated with geometry self-efficacy.

The last finding is that "Positive self-efficacy beliefs" explains $58 \%$ of the variance in the attitude towards geometry, "Use of geometry knowledge" explains $2 \%$ of the variance, "Negative selfefficacy beliefs" explain 3\%, and "Spatial anxiety" explains $1 \%$ of the variance. Thus, the variables used in the current study explain $64 \%$ of the total variance in the attitude towards geometry. "Positive self-efficacy beliefs", "Use of geometry knowledge", and "Negative selfefficacy beliefs" were found to positively affect the attitude towards geometry. However, "Spatial anxiety" ( $\beta=-.077, p<.05)$ was found to have a negative and weak effect on explaining the attitude towards geometry.

\section{CONCLUSION}

When all these results are considered together, it can be concluded that the effective features are critical ineffective learning of geometry and one of its components, spatial skills. In this context, it is thought that pre-service teachers' self-efficacy beliefs will affect their attitudes towards geometry and thus, can help them increase their geometry achievement. Moreover, the results of this study has shown that pre-service teachers' geometry self-efficacy largely explains the positive attitudes of pre-service teachers towards geometry. Moreover, when preservice teachers' attitudes towards geometry and self-efficacy beliefs are determined and the necessary measures are taken in this regard, it will be possible for them to arrange themselves in such a way as to respond to the needs of students in their future professional career and to determine and manage students' need for learning geometry. Although low values have been obtained in this study, reduction of spatial anxiety in pre-service teachers can contribute to the development of positive attitudes towards geometry.

\section{REFERENCES}

Abalı Öztürk, Y., \& Şahin, Ç. (2015). Matematiğe ilişkin akademik başarı, özyeterlilik ve tutum arasındaki iliskkilerin belirlenmesi [Determining the relationships between academic achievement, self-efficacy and attitudes towards maths]. The Journal of Academic Social Science Studies, 31, 343-366. https://doi.org/10.9761/JASSS2621

Avcu, R., \& Avcu, S. (2015). Turkish adaptation of Utley geometry attitude scale: A validity and reliability study. Eurasian Journal of Educational Research, 8, 1-24. 
Alper Yorulmaz and Emel Çilingir Altıner, Do Geometry Self-Efficacy and Spatial Anxiety Predict...

https://doi.org/10.14689/ejer.2015.58.1

Ayotola, A., \& Adedeji, T. (2009). The relationship between mathematics self-efficacy and achievement in mathematics. Procedia-Social and Behavioral Sciences, 1 (1), 953-957. https://doi.org/10.1016/j.sbspro.2009.01.169

Bal, A. P. (2012). Teacher candidates' geometric thinking levels and attitudes to geometry. Journal of Educational Sciences Research, 2(1), 17-34. Retrieved from https://dergipark.org.tr/tr/pub/ebader/issue/44650/554613

Bayturan, S. (2011). Ortaöğretim matematik eğitiminde bilgisayar destekli öğretimin, öğrencilerin başarıları, tutumları ve bilgisayar öz-yeterlik algıları üzerindeki etkisi [The effect of computer-assisted instruction in secondary education mathematics on students' achievement. Unpublished doctoral dissertation, Dokuz Eylül University, Institute of Educational Sciences, İzmir.

Bindak, R. (2004). Geometri tutum ölçeği güvenirlik çalışması ve bir uygulama [Study of reliability and validity with an application for geometry attitude scale]. Unpublished Doctoral Dissertation, Dicle Üniversity, Diyarbakır.

Büyüköztürk, Ş., Çakmak, E., Akgün, Ö., Karadeniz, Ş., \& Demirel, F. (2013). Bilimsel araştırma yöntemleri [Scientific research methods]. Ankara: Pegem Akademi.

Çağlayan, S. (2010). Lise 1. sınıf öğrencilerinin geometri dersine yönelik özyeterlik algısı ve tutumunun geometri dersi akademik başarııını yordama gücü [The potential of predictive of the academic achievement points of geometry using the 9th grade students' geometry self-e. Unpublished Master Thesis, Yıldız Teknik Üniversity, İstanbul.

Canturk-Gunhan, B., \& Baser, N. (2007). The development of self-efficacy scale toward geometry. Hacettepe University Journal of Education, 33, 68-76. Retrieved from http://www.efdergi.hacettepe.edu.tr/yonetim/icerik/makaleler/1006-published.pdf

Çelik, E. (2012). Matematik problemi çözme başarısı ile üstbilişsel özdüzenleme, matematik özyeterlik ve özdeğerlendirme kararlarının doğruluğu arasındaki ilişkinin [Examining the relationship between success in solving mathematical problems and the accuracy of metacognitive]. Unpublished Doctoral Dissertation. Marmara Üniversity, İstanbul.

Duatepe-Paksu, A. (2013). Sınıf öğretmeni adaylarının geometri hazırbulunuşlukları, düşünme düzeyleri, geometriye karşı öz-yeterlikleri ve tutumları [Preservice elementary teachers' geometry readiness, thinking levels, self-efficacy and attitudes towards geometry]. Pamukkale University Journal of Education, 33, 203-218. https://doi.org/10.9779/PUJE585

Dursun, Ö. (2010). The relationships among the preservice teachers' spatial visualization ability, geometry self-efficacy, and spatial anxiety. Unpublished Master's Thesis, Middle East Technical University, Ankara.

Erkek, Ö., \& Işıksal-Bostan, M. (2015). Uzamsal kaygı, geometri öz-yeterlik algısı ve cinsiyet değişkenlerinin geometri başarısını yordamadaki roller [The role of spatial anxiety, geometry self-efficacy and gender in predicting geometry achievement]. Elementary Education Online, 14 (1), 164-180. https://doi.org/10.17051/io.2015.18256

Field, A. (2009). Discovering statistics using SPSS (3rd ed.). London: Sage Publications.

Fraenkel, J. R., Wallen, N. E., \& Hyun, H. H. (2019). How to design and evaluate research in education (10th ed.). New York: McGraw-Hill Companies.

Gunderson, E. A., Ramirez, G., Beilock, S. L., \& Levine, S. C. (2013). Teachers' spatial anxiety relates to 1st- and 2nd-graders' spatial learning. Mind, Brain and Education, 7(3), 196-199. https://doi.org/10.1111/mbe.12027

Işıksal, M., \& Aşkar, P. (2003). İlköğretim öğrencileri için matematik ve bilgisayar özyeterlik algısı ölçekleri [The scales of perceived mathematics and computer self-efficacy for elementary students]. Hacettepe University Journal of Education Faculty, 25 (25), 109-1 18. Retrieved from http://www.efdergi.hacettepe.edu.tr/yonetim/icerik/makaleler/870- 
published.pdf

Kitsantas, A., Cheema, J., \& Ware, H. (2011). Mathematics achievement: The role of homework and self-efficacy beliefs. Journal of Advanced Academics, 22(2), 310-339. https://doi.org/10.1177/1932202X1102200206

Kline, R. B. (2010). Principles and practice of structural equation modelling (3rd ed.). New York: Guilford Press.

Lawton, C. A. (1994). Gender differences in way-finding strategies: Relationship to spatial ability and spatial anxiety. Sex Roles, 30(11-12), 765-779. https://doi.org/10.1007/BF01544230

Milli Eğitim Bakanlığı-Ölçme Değerlendirme ve Sınav Hizmetleri Genel Müdürlüğü (Ministry of National Education-General Directorate of Assessment, Evaluation and Examination Services). (2016). Uluslararası matematik ve fen eğilimleri araştırması (TIMSS) 2015 ulusal matematik ve fen ön raporu [Trends in International Mathematics and Science Study (TIMSS) 2015 National Mathematics and Science Preliminary Report]. MoNE Publications. Ankara.

Mullis, I. V., \& Martin, M. O. (2017). TIMSS 2019 Assessment frameworks. International Association for the Evaluation of Educational Achievement. Herengracht 487, Amsterdam, 1017 BT, The Netherlands.

NCTM. (2000). Principles and standards for school mathematics. Reston, VA: NCTM Publications.

Öztürk, B. (2017). Ortaokul öğrencilerinin üstbilişsel farkındalık düzeyi ile matematik öz yeterlik algısının matematik başarııına etkisinin incelenmesi [The analysis of the effect of metacognitive awareness and mathematics self-efficacy perceptions on mathematics achievement]. Unpublished Master's Thesis, Eskişehir University, Eskişehir.

Pajares, F., \& Miller, M. D. (1994). Role of self-efficacy and self-concept beliefs in mathematical problem solving: A path analysis. Journal of Educational Psychology, 86(2), 193-203. https://doi.org/10.1037/0022-0663.86.2.193

Papanastasiou, C. (2000). Effects of attitudes and beliefs on mathematics achievement. Studies in Educational Evaluation, 26(1), 27-42. https://doi.org/10.1016/s0191$491 \times(00) 00004-3$

Sokolowski, H. M., Hawes, Z., \& Lyons, I. M. (2019). What explains sex differences in math anxiety? A closer look at the role of spatial processing. Cognition, 182, 193-212. https://doi.org/10.1016/j.cognition.2018.10.005

Terzi, M., \& Mirasyedioğlu, Ş. (2009). İlköğretim matematik öğretmen adaylarının matematiğe yönelik özyeterlik algılarının bazı değişkenler açısından incelenmesi [Analysis of department of elemantary mathematics teaching students' perceived mathematics selfefficacy in terms of some variables]. TÜBAV Science Journal, 2(2), 257-265. Retrieved from https://dergipark.org.tr/en/pub/tubav/issue/21515/614976

Thompson, K. M. (1993). Geometry students' attitudes toward mathematics: an empirical investigation of two specific curricular approaches. Unpublished Master's Thesis, California State University Dominguez Hills, USA.

Tsao, Y. L. (2017). Pre-service elementary school teachers' attitude towards geometry. US-China Education Review B, 7(1), 15-22. https://doi.org/10.17265/2161-6248/2017.01.002

Ünlü, M., Avcu, S., \& Avcu, R. (2010). The relationship between geometry attitudes and selfefficacy beliefs towards geometry. Procedia-Social and Behavioral Sciences, 9, 13251329. https://doi.org/10.1016/j.sbspro.2010.12.328

Utley, J. G. (2004). Impact of a non-traditional geometry course on prospective elementary teachers' attitudes and teaching efficacy. Unpublished Ph.D. Dissertation, Oklahoma State University, Oklahoma, USA.

Wai, J., Lubinski, D., \& Benbow, C. P. (2009). Spatial ability for STEM domains: Aligning over 50 years of cumulative psychological knowledge solidifies its importance. Journal of 
Alper Yorulmaz and Emel Çilingir Altıner, Do Geometry Self-Efficacy and Spatial Anxiety Predict...

Educational Psychology, 101 (4), 817-835. https://doi.org/10.1037/a0016127

Yenilmez, K., \& Uygan, C. (2010). Yaratıcı drama yönteminin ilköğretim 7. sınıf öğrencilerinin geometriye yönelik öz-yeterlik inançlarına etkisi [The effects of creative drama method on 7th grade students' self-efficacy beliefs on geometry]. Kastamonu Education Journal, 18(3), 931-942.

Retrieved

from https://dergipark.org.tr/en/pub/kefdergi/issue/49056/625884

Zimmerman, B. J. (1995). Self-efficacy in changing societies. In A. Bandura (Ed.), Self-efficacy and educational development (pp. 202-231). New York: Cambridge University Press. 